\title{
NEUROPSYCHOLOGICAL CORRELATES OF INTERNET ADDICTION
}

\author{
Nada Pop-Jordanova ${ }^{1}$ and Sofija Loleska ${ }^{2}$
}

${ }^{1}$ Macedonian Academy of Sciences and Arts

${ }^{2} \mathrm{PhD}$ Student at the Faculty of Medicine, Ss. Cyril and Methodius University, Skopje, North Macedonia

Corresponding author: Nada Pop-Jordanova, Bul Krste Misirkov br. 2, P.O.Box 428, 1000 Skopje, RN Macedonia, e-mail: popjordanova.nadica@gmail.com

\section{ABSTRACT}

The Internet, mobile phones, and other similar tools are often necessary for the current functioning of both private life and business. During these two years of pandemic (2019-2021), Internet use, especially different games and mobile phones, were indispensable for the global population.

Internet addiction is defined as a psychological dependence on the internet, regardless of the type of activity once logged on. Many studies have confirmed the correlation of stress, depression, and anxiety with internet addiction. It has also been proven that internet addiction, per se, increases the risk of depression, anxiety, and stress. Moreover, the COVID-19 pandemic has generated and promoted social isolation along with unmonitored and increased screen time, all of which are the main causes of internet addiction.

The aim of this article is to give a short review of internet addiction research, terminology, and symptoms related to brain functioning. The source material was articles cited in the database, PubMed. Our interest was especially oriented towards the personality characteristics of users and addicted persons as well as neuroimage findings among affected people. We selected the newest articles, published in the period of 2012-2021, of which there are more than 2000. The selected obtained results will be presented and discussed.

Keywords: internet addiction, psychological factors, neuroimaging

\section{INTRODUCTION}

The internet, mobile phones, and other similar tools are indispensable for the current functioning of both private life and business. The diversity of possibilities for communication, entertainment, and dealing with everyday requirements allow easier and faster ways to function. However, the growing use (or misuse) of all of these tools over the past few decades has provoked extensive and massive negative consequences. Our project was financed by the European cooperation in science \& technology (EU/ESF-COST BMO 704) "Emerging EMF Technologies and Health Risk Management". This aforementioned study confirms some negative health effects due to electromagnetic waves used in medicine, industry, and mobile phones. During this period, we found that over $98 \%$ of our school children possessed a mobile phone and used it frequently on a daily basis. A hypersensitive reaction was proven in a significant number of these students (Pop-Jordanova, 2012). [1] 
In these two years of pandemic (2019-2021), internet use, especially for different games as well as mobile phones, were indispensable for the global population. internet games are especially linked to social interaction, allowing engagement and interaction among many people online in a virtual world. However, most people experienced a loss of control over their internet use and reported social problems and difficulties in work as well in school. This is generally labelled as internet Addiction(IA). internet addiction can be defined as an overuse of the internet, leading to impairment of an individual's psychological state (both mental and emotional), as well as their scholastic or occupational and social interactions. internet addiction has become a serious behavioural health problem in the entire world. ( Kwok-Kei Mak et all, 2014) [2]

The aim of this article is to give a short review of internet addiction research, clarify the terminology and symptoms related to brain function. The source material was articles cited in the database, PubMed. Terms such as internet, addiction, internet disorder, brain, prefrontal cortex, neuroimaging were used as key words. Our interest was especially oriented towards the personality characteristics of users and addicted people. We selected the newest articles, published in the period between 2012-2021, of which there are more than 2000 . Selected obtained results will be presented and discussed.

\section{EPIDEMIOLOGY}

Early detection of the causes of graft dysfunctProblematic computer use is a growing social issue which is being debated worldwide. Internet Addiction Disorder ruins lives by causing neurological complications, psychological disturbances, and social problems. The prevalence of internet addiction disorder is changing every day, but general prevalence rates are between 1.5 and $8.2 \%$ in Europe and USA (Weinstein A. 2010). [3] Around $5.8 \%$ of adolescents and $2.8 \%$ of young adults have an internet-related disorder (Geisel O.2021). [4] The German STICA study (Short-term Treatment of Internet and Computer game Addiction) showed an interesting fact - female adolescents are statistically significantly more often affected than male adolescents ( $7.1 \%$ versus $4.5 \%)$.

In Asia, this problem is rising significantly: the overall prevalence of smartphone owner- ship is $62 \%$, ranging from $41 \%$ in China to $84 \%$ in South Korea. Moreover, participation in online gaming ranges from $11 \%$ in China to $39 \%$ in Japan. Hong Kong has the highest number of adolescents reporting daily or above average internet use (68\%). However, internet addiction is highest in the Philippines. Problematic internet use is prevalent and characterized by risky cyber behaviours (Kwok-Key, 2014).

Internet addiction, online gaming disorder, online gambling disorder, pornography use, and smartphone use disorder are have grown especially during the 2020-21 Covid-19 pandemic. (Masaeli, 2021). [5] Internet addiction statistics for 2020-21 (Zuckerman a. 2020) [6] show, that in April 2020,59\% of the global population of approximately 4.57 billion people were active internet users. In terms of penetration, $58.7 \%$ of the global population has internet access. Of the total number of internet users, $50.3 \%$ are in Asia, $15.9 \%$ in Europe, $11.5 \%$ in Africa, $10.1 \%$ Latin America, 7.6\% North America, 3.9\% Middle East, and $0.6 \%$ in Oceania. In addition, 4.2 billion people were active mobile internet users, 3.81 billion were active social media users, whereas 3.76 were active mobile social media users.

Moreover, $59.3 \%$ of the adult Chinese population are active internet users. On the other hand, $89 \%$ of the population in USA are active internet users.

Looking at it from a regional perspective, North America has the highest internet penetration at $94.6 \%$. Other regions on the top of list include Europe (87.2\%), Latin America (70.5\%), the Middle East (69.2\%), Oceania (67.4\%), Asia (53.6\%), and Africa (39.3\%).

Very interesting, however, is the data which shows the prevalence rate of IA in medical professionals which is purported to be about $9.7 \%$ and was associated with greater mental symptoms and fatigues among healthcare workers (Buneviciene I., 2021). [7]

One of the more shocking social media facts and statistics is that by 2021, the monthly number of active social media users is expected to reach 3.02 billion globally.

\section{TERMINOLOGY}

There are different terms in the scientific literature when referring to an overuse of the inter- 
net, such as internet addiction, compulsive internet use, internet-related addictive behaviour, internet-related problems, problematic internet use, pathological internet use, online gaming disorder, online gambling disorder, pornography use, and smartphone use disorder. While there is great consensus about the multiple applications the internet provides and which can be addictively used (such as gaming and gambling, pornography, social networking sites, shopping sites, and so on), only Internet Gaming Disorder has recently been included in the appendix of the DSM-5 (APA, 2013), making it clear that more research is needed on this phenomenon in order to collect evidence for its clinical relevance and underlying mechanisms.

The criteria proposed for diagnosing IA are: preoccupation with internet games, withdrawal symptoms of irritability, anxiety, or sadness, development of a tolerance towards unsuccessful attempts to control the behaviour, loss of interest in other activities, continued excessive use, despite knowledge of psychosocial problems, deceiving others regarding the amount of time spent on gaming, use of this behaviour to escape or relieve a negative mood, and jeopardizing/losing a significant relationship/job/educational opportunity. The articles found in this review proved an increase in internet-based addictive behaviours during the COVID-19 pandemic, mostly due to financial hardship, isolation, problematic substance use, and mental health issues such as depression, anxiety, and stress.

\section{PSYCHOLOGICAL CHARACTERISTICS}

As a psychologist and paediatrician, and having a computer scientist as a co-author, we have been very interested in the personality characteristics (if any exist) among young people who addicted to this modern tool.

Many studies investigate possible predisposing factors, vulnerability factors, and correlates of IA. We will mention some of these. Psychometric results suggest that pathological internet gamers, in general, exhibit self-concept deficits in their body image as well as in social and emotional competencies, compared to healthy controls. They also exhibit more social anxiety symptoms. For this research, the most used psychometric instrument is the Big-Five (Goldberg, 1992). [8]

The study of Tian Yu et al. 2021, [9] examined the longitudinal association among the BigFive personality traits, maladaptive cognitions, and internet addiction during the COVID-19 pandemic in a sample of Chinese students. The results of the analysed data showed that (a) extraversion, agreeableness, conscientiousness, and openness were negatively associated with maladaptive cognitions and internet addiction, whereas neuroticism was found to be positively associated with maladaptive cognitions and internet addiction

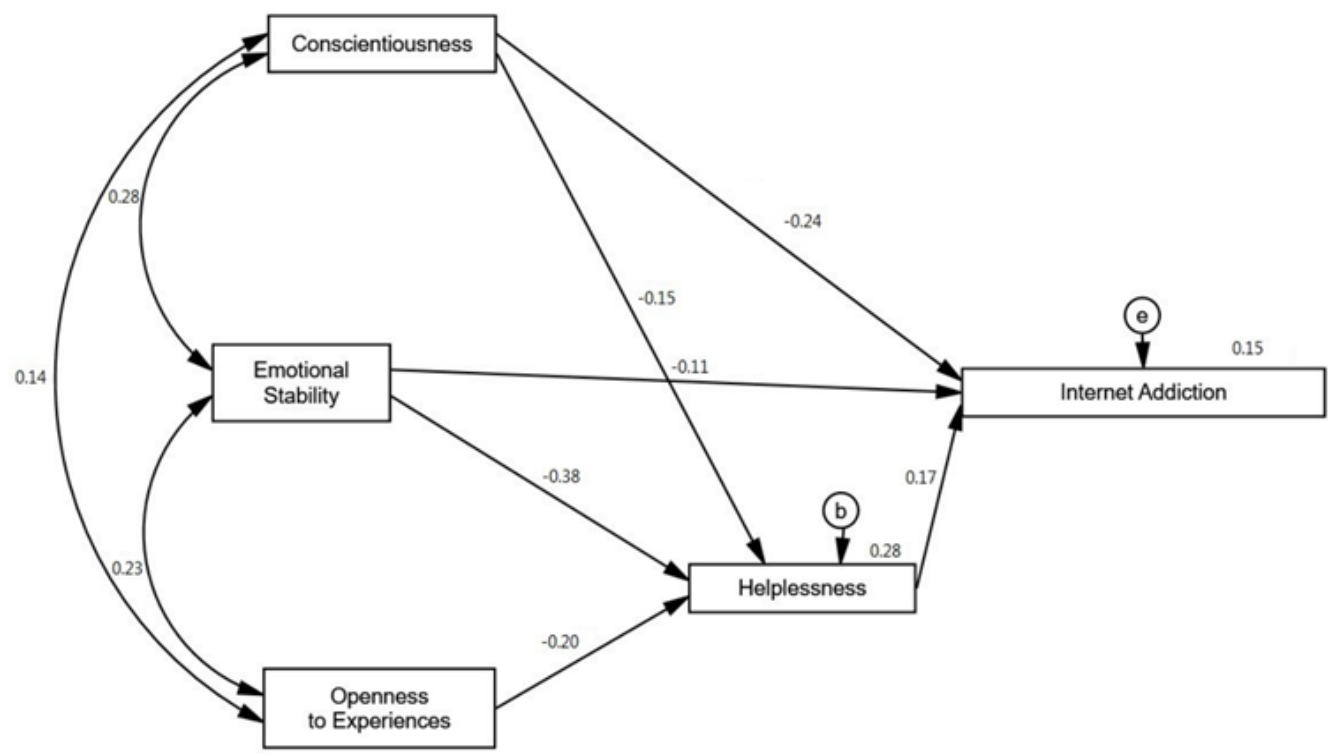

Figure 1. A model explaining internet addiction using personality traits and coping strategies

[Chwaszcz J. et al, 2018] 
across time; (b) associations among the BigFive personality traits, maladaptive cognition, and internet addiction were dynamic and bidirectional; and (c) maladaptive cognition played a mediating role in extraversion, agreeableness, conscientiousness, openness, and internet addiction across time. The Big-Five personality traits, maladaptive cognition, and internet addiction predicted each other across time, and maladaptive cognition was likely to be the key mediating factor in the association between the Big-Five personality traits and internet addiction.

The study of Zhang Yue et al, 2021 [10] highlights that impulsivity, social support, and depression may predict internet addiction among male college freshmen. This finding must be used in preventive actions.

Chwaszcz J. et al, 2018 [11] studied the relationship between personality dimensions and strategies of coping with stress and the level of internet addiction. The obtained results demonstrated a major role of personality-related factors in the development of internet addiction. The key issue is the attitude towards difficulties. The findings presented in this study also make it possible to delineate areas for improvement (e.g., through psychoeducational intervention) to protect young people from the risk of developing the addiction. Fig. 1, borrowed from this study, shows the relationships between personality traits and IA.

In this model, the variables that best explain the level of internet addiction were conscientiousness, emotional stability, and openness to experience, and helplessness as a complex coping strategy. These variables accounted for $15 \%$ of the variance in internet addiction. All the paths included in the model are statistically significant. Low conscientiousness can directly contribute to the development of the addiction. In the case of openness to experience, this correlation is mediated by helplessness. With regard to emotional stability, its impact on internet addiction is both direct and mediated by helplessness. Low emotional stability contributes to problematic internet usage, but can also make the individual more helpless, which, in turn, increases the risk of internet addiction. It was highlighted that helplessness is a partial mediator between internet addiction and conscientiousness, just as it is between internet addiction and emotional stability. On the other hand, helplessness is a full mediator between openness to experience and problematic internet use.

The research of Farahani $M$ et al, 2018 [12] confirmed that narcissistic personality, obsessive- compulsive personality, anxiety, bipolar disorders, depression, and phobia could increase the odds ratio (OR) of internet significantly ( $p$-value $<0.05$ ), however, other psychiatric or personality disorders did not have a significant effect on the internet addiction.

Having in mind that stress, coping mechanisms, and anxiety are often correlated with IA, the study of Cerniglia L. et al, 2020 [13] aims to investigate the possible association between IA and genetic polymorphisms in monoamine oxidase A (MAO-A), serotonin-transporter (5-HTTPR), dopamine receptor (DRD4), and dopamine transporter (DAT1) genes related to problems related to depression, anxiety, and avoidant personality in young people. This exploratory study supports the recent evidence on the mutual relationship between biological, individual, and social risk factors associated with IA in young adulthood. These findings may have important clinical implications for the development of prevention and treatment programs.

Lo et al. (2020) [14], in their study dedicated to the investigation of the causes and risk factors for IA, indicated that worry was related to greater internet addiction among children. Furthermore, they found a moderating effect of permissive parenting style and IA. More pre-

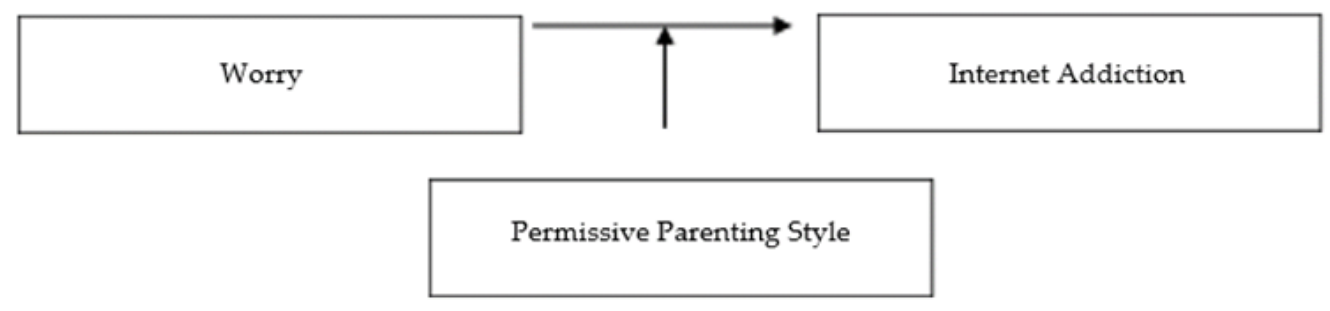

Figure 2. Hypothesized moderating effect of the permissive parenting style and worry for IA

[Lo et al.,2020] 
cisely, there is a positive association between worry and internet addiction if permissive parenting style is higher. These findings imply that parenting styles are influential in the prevention of internet addiction which is presented in summary on Fig 2.

The association between perfectionism and addictive behaviours was the topic of many studies. The recent study of Yang et al (2021) [15] indicated that maladaptive perfectionism was directly related to students' internet addiction and indirectly predicted students' internet addiction via the mediator of depression. Gender moderated the direct effect of maladaptive perfectionism on IA, showing a stronger addiction in males.

Together with the internet, smartphone use is also a current problem, especially among the younger population. Associations between personality traits and problematic smartphone use among individuals with substance use disorder have been investigated in a study of Demkow-Jania M. et al., 2021 [16]. Smartphone use appeared as a moderator for individuals with substance use (as presented below). As personality traits, they found that neuroticism and openness to new experience were associated in people who use substances. The authors concluded that addictive people are influenced by personality traits for problematic mobile phone use. Fig 3. shows the relationship between the aforementioned factors.

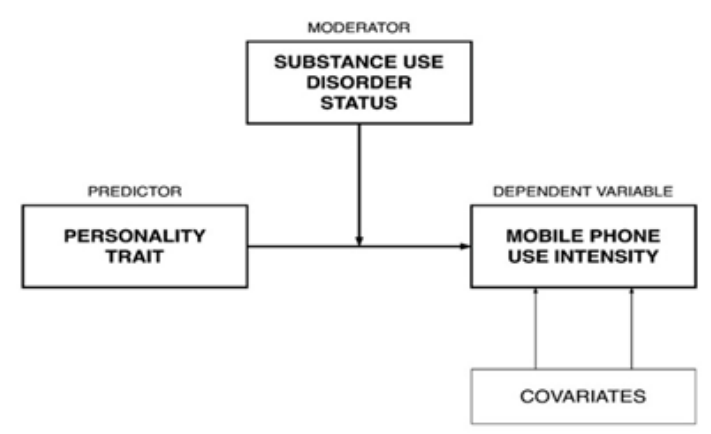

Figure 3. Personality traits, substance use and intensity of smartphone use

[Demkow-Jania M. et all, 2021]

The dark triad of personality comprises three intercorrelated but distinct socially aversive personality traits, namely Machiavellianism, narcissism, and psychopathy, manifested on a subclinical level. The dark triad traits are also potentially associated with the IA. Machiavellianism correlates positively with the entertain- ment preferences for violent video games as well as with gambling behaviour, and high scores in narcissism have been associated with disordered gambling behaviour and compulsive buying. Psychopathy has been associated with entertainment preferences for violent video games. The conclusion of the study by Sindermann C. et al. (2018) [17] was that the associations found between the dark triad traits and unspecified IA are similar in males and females.

Problematic internet use is an increasingly worrisome issue, as youth population studies are establishing links between internalizing and externalizing problems. Restrepo A. et al. (2020) [18] examined the association between IA and psychopathology, general impairment, physical health, and sleep disturbance. They confirmed a positive association between IA and psychopathology, especially depression, combined ADHD, being on the autistic spectrum, and sleep disturbance.

In general, many studies have confirmed that some psychological traits could be predisposing factors (such as depression, worry, emotional instability, bad coping strategies, etc.) for IA and these finding must be considered when preventive measures are planned.

Along with the increased risk of having psychological symptoms of depression, anxiety, and stress due to the impact of the pandemic, researchers have warned about the increased risk of developing a behavioural addiction, such as internet gaming disorder (IGD), which is known to be more prevalent in males, in particular among adolescents. The Diagnostic and Statistical Manual of Mental Disorders 5 (DSM-5) outlines the following symptoms as criteria for internet gaming disorder: preoccupation, withdrawal, tolerance, failure to reduce or stop gaming, neglecting other activities, continuing gaming despite problems, deception, gaming to escape, and relationship risk due to excessive gaming. There has been a heightened risk for adolescents to develop IGD during the COVID-19 pandemic.

The addictive internet gaming usage scores of profiles in Korean adolescents are presented in Fig. 4 (Kim D., Lee J., 2021) [19]

Compared to 2018, there is a great difference in time consumed on the internet between adolescents in Korea during the pandemic period of 2020 (Fig. 5). 


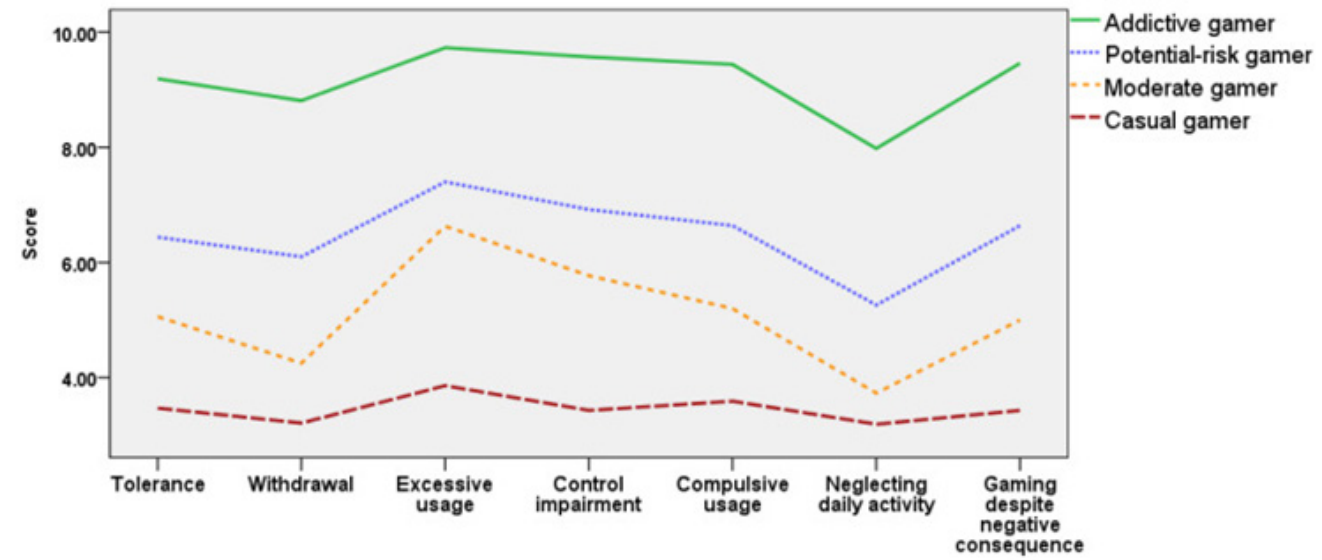

Figure 4. Profiles of addictive internet gaming usage of the 2020 cohort.

[Kim D., Lee J., 2021]

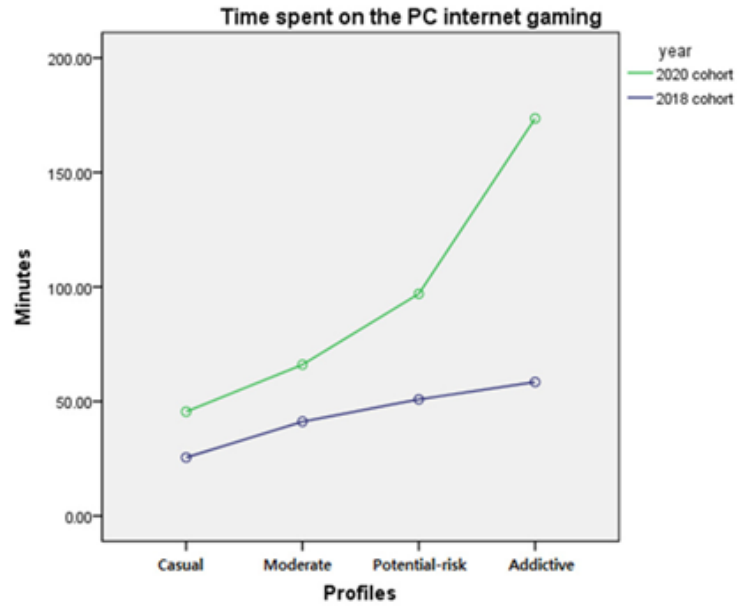

Figure 5. Interaction of profile membership and year on PC internet gaming time (comparison between data for 2018 and 2020).

\section{NEUROIMAGING RESEARCH}

A very interesting issue is how the brain functions when the individual has IA. The question arising here is whether there are some specific changes in neuron function, connections, and the brain area related to IA.

Research in this area has showed that the severity of IA is related to the following factors: amount of e-messaging, used social networking services, games, internet gambling, holiday internet usage, using internet for educational purposes, age of first exposure to the internet, and especially sleep duration.
There are a growing number of studies on structural and functional brain mechanisms underlying internet gaming disorder in particular. Functional magnetic resonance in adolescents with this addiction has shown lower white matter volume in regions associated with attention motor coordination, executive function, and perception, as well as emotional regulation. Having similar brain dysfunction in ADHD patients, it was suggested that internet gaming disorder could be a related comorbidity with ADHD and depression (Weinstein A. M. (2017). [20] Figure 6 shows brain regions which are involved in different types addictions for internet use. 

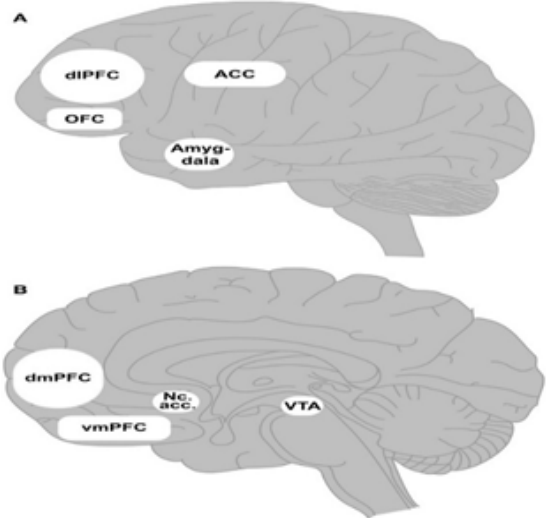

Figure 6. The prefrontal cortex regions and associated brain structures most likely involved in development and maintenance of an addictive use of the internet (Brand, 2014) [21]

(A) Shows the lateral view of the brain including medial parts such as anterior cingulate gyrus and amygdala, and (B) illustrates the medio-sagittal view of the prefrontal cortex.

Addiction to social networks, on the other hand, seems to be characterized by deficits in emotion regulation, leading to reduced self-satisfaction, which is, in turn, reflected by a lower

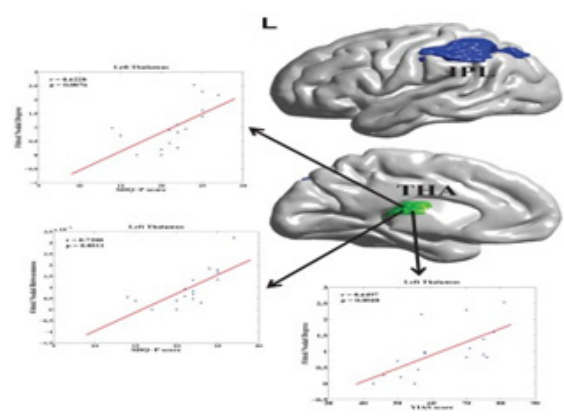

Figure 7. The brain regions that are significantly correlated with behavioural and clinical scores in the IA [Chong-Yaw Wee et al., 2014]
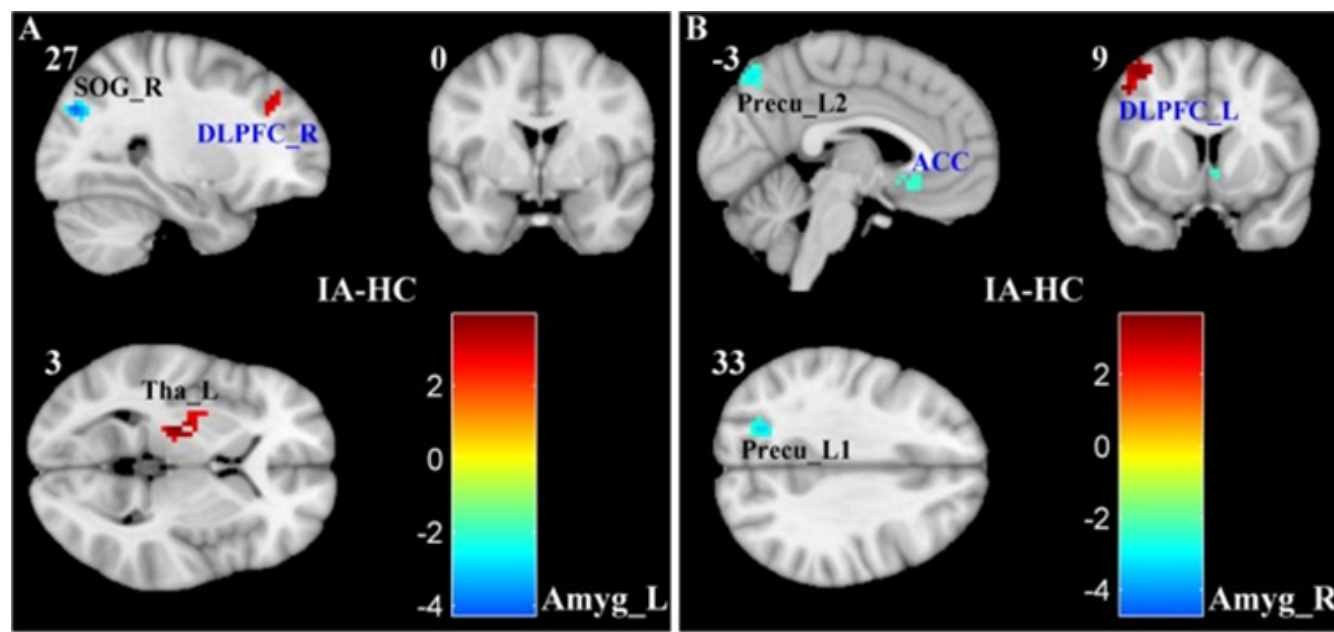

Figure 8. Altered functional connectivity between amygdala and prefrontal cortex (PFC) in subjects with IA. [Cheng H. 2020] number of striatal activations during self-reflection, compared to healthy controls.

Yet, in Chong-Yaw Wee et al. 2014 22, they demonstrated that there is significant disruption in the functional connectome of IA patients, particularly between regions located in the frontal, occipital, and parietal lobes. The affected connections are long-range and inter-hemispheric connections. In addition, correlation analysis demonstrates that the observed regional abnormalities are correlated with the severity of IA and behavioural clinical assessments. (Fig.7)

Concerning emotional imbalance, the recent study of Cheng H. (2020)23 confirmed some structural and functional abnormalities in the amygdala, due to IA. As known, the amygdala is responsible for emotional cognition interactions. People with IA showed decreased functional brain connectivity especially between the amygdala and the dorsolateral prefrontal cortex, but increased connectivity between the amygdala and the precuneus and superior occipital gyrus (Fig. 8). These changes are related to the duration of IA.

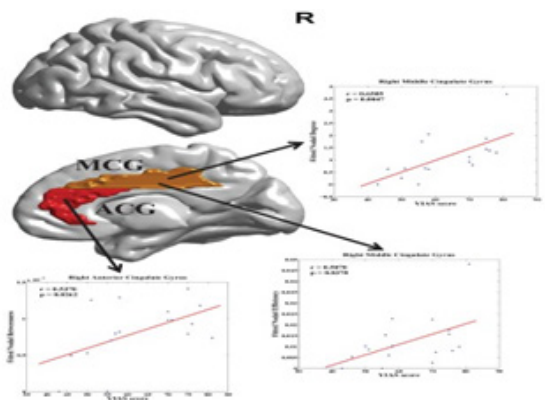


Similar findings related to brain connectivity are published by Baojuan Li et al., (2014) [24] (see Fig. 9)

The next important question related to the misuse of the internet and mobile phones relates to suicidal tendencies and the rate of suicides, especially among the younger population. Why suicide? As shown, the overuse of different social media tools is related with alienation, depression, loneliness, low self-esteem, emotional imbalance, and changed ethical norms. In this context, the suicide rate in the USA has drastically changed, if one compares the data is from 2016 and 2000 year (Fig.10), especially in younger people.

Suicidal attempts are interesting from a neuroimaging aspect, too. Fig. 11 shows brain maps indicating the difference of the more activated region in the suicidal group compared with the normal control group.

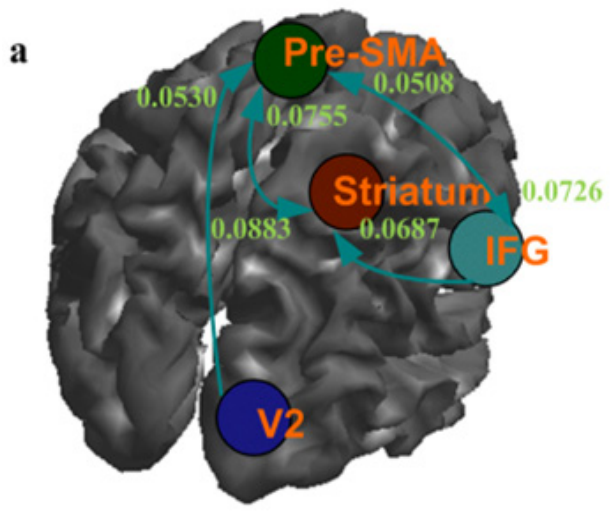

Controls
The yellow part indicates the increased amplitude of low-frequency fluctuation values of the suicidal attempt group compared with the non-suicidal attempt group. B displays the images shown in A after three-dimensional reconstruction. Yellow indicates the position with abnormal changes. [Yan Huang et al 2020] [26]

IA is especially linked with pornography, presented online and available through Pornhub (a YouTube-like website for pornography). As expected, online pornography use has become globally prevalent, especially during the period of lockdowns. In this context, over 42 billion adults visited the Pornhub website in 2019, averaging 115 million visits daily.

Data obtained during the Covid-19 pandemic showed an increase in traffic on Pornhub (Hashir Ali Awan et al, 2021)27 (Fig. 12)

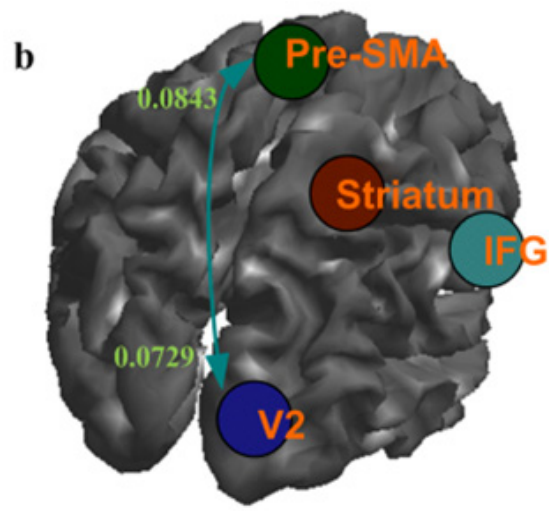

IA

Figure 9. Effective connectivity within the response inhibition network, in the controls and IA subjects. [Baojuan Li et al, 2014]

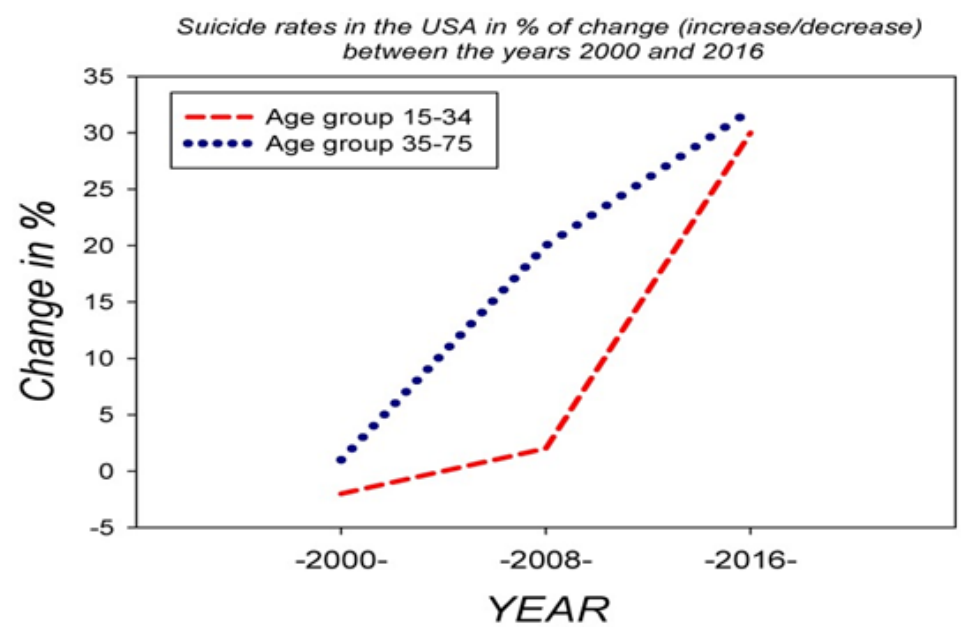

Figure 10. Estimates for suicide rates in the USA, which has an internet penetration index of $92 \%$ of the global population, between the years 2000 and 2016. [Birgitta Dresp-Langley, 2020] 
A

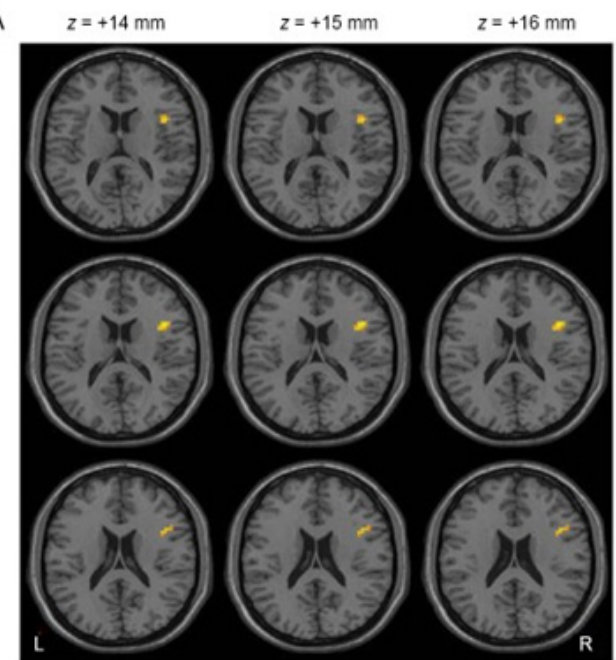

B
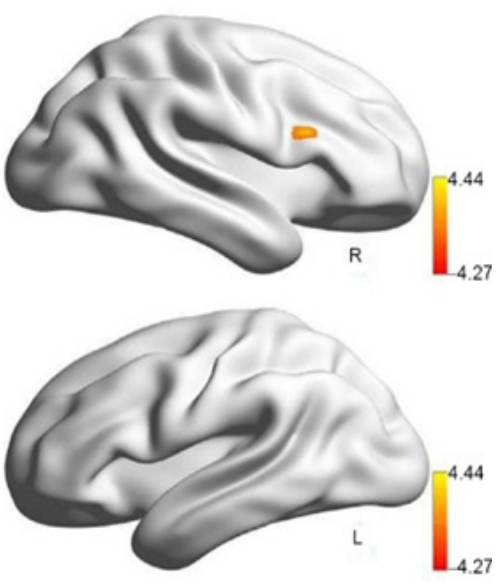

Figure 11. Statistical maps indicating t-test results of the z-score of the amplitude of low-frequency fluctuation differences between the suicidal attempt and non-suicidal attempt groups.

[Yan Huang et al 2020]
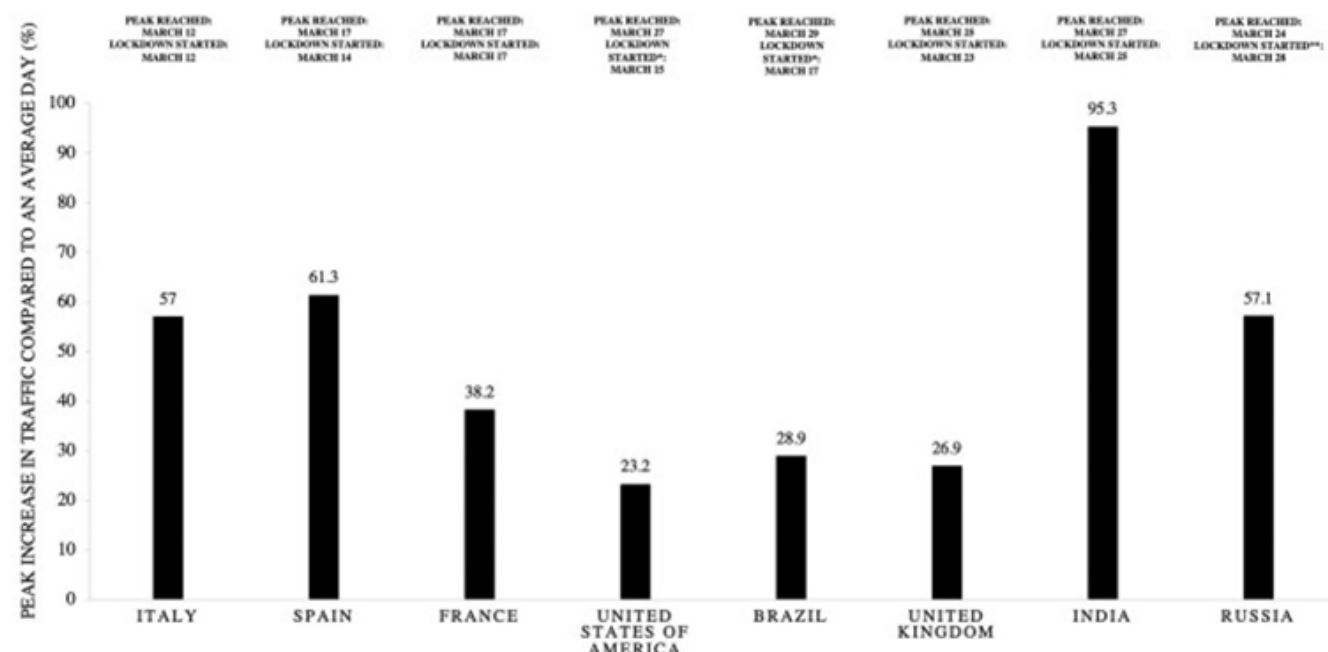

Figure 12. Peak Increase in Traffic compared to an average day

(before the pandemic) on Pornhub $₫$ during COVID-1 [Hashir Ali Awan et al, 2021]

As can be seen from the figure, India is the nation with the highest peak registered for this problem, but Italy, Spain, and Russia are also quite high. We still not have data for our country, Macedonia, but we have supposed a similar growth of the percentage of visits during lockdowns.

\section{CONCLUSION}

We can say that the problem of IA has been rising and has continued to do so over the course of the last two decades. It is especially current during the period of the COVID-19 pandemic, a time of lockdowns, restrictions, economic crises, unemployment, etc. All of these factors can lead to different psychological disorders, addiction, and unhealthy behaviour. The results of this review have provided evidence for the increase in internet-based addictive behaviours, however, the GRADE approach (The Grades of Recommendation, Assessment, Development and Evaluation Working Group) has confirmed a very low to moderate quality of available evidence as well as insufficient quantitative studies for all online behaviors, particularly pornography and smartphone use disorder. 
There is a need for more research in order to better understand how COVID-19 affects the onset, maintenance, and relapse potential for some of the most common internet-based addictive behaviours among the general population, especially in young people. Furthermore, there is a need to study of the role of psychological processes, addictive behaviour, and health behaviour in terms of the onset and maintenance of COVID-19 infection and the burdens of stress. There will be a demand for preventative and interventive efforts for managing the impact of COVID-19 among individuals with elevated negative mood symptoms and internet-based addictive behaviour.

It was accentuated that some personality traits could be provocative factors for IA behaviour. The lack of enough qualitative studies limits the generalizability of some findings, and some conclusions are speculative. As all conclusions are based on current literature data, they are therefore only preliminary. Improving online counselling services will have a significant longterm positive impact on stressed individuals, which will remain even after this pandemic passes. Effective intervention should be scaled up in order to prevent and reduce internet-based addictive behaviours. Accessible guidelines should also be created, particularly for adolescents. In this context, children returning to school, the restricted use of smartphones, computers and internet, and the encouragement of sports activities could be some preventive measures. Technological development is not adequately followed by human development and ethical norms, either.

Finally, it must be pointed out that there is an urgent need to introduce and implement new interventions for different at-risk populations, conduct well-designed research, and publish data on the effectiveness of these interventions. The development of preventative interventions should primarily target children and adolescents at risk of internet addiction but also parents, teachers, peers, and others who are part of the formative environment of children and adolescents at risk of internet addiction.

\section{REFERENCES}

1. Pop-Jordanova N., Pop-Jordanova S. (2012) Health symptoms caused by electromagnetic radiation, Physioacta; 6 (2): 33-45.
2. Kwok-Kei Mak, Ching-Man Lai, Hiroko Watanabe, Dong-Il Kim, Norharlina Bahar, Milen Ramos, Kimberly S. Young, Roger C.M. Ho, $\mathrm{Na}-\mathrm{Rae}$ Aum, and Cecilia Cheng. (2014) Cyberpsychology, Behavior, and Social Networking.: 720-728.

3. Weinstein A, Lejoyeux M. (2010) Internet addiction or excessive Internet use. The American Journal of Drug and Alcohol Abuse.;36(5):277-83.

4. Geisel, O., Lipinski, A., \& Kaess, M. (2021). Non-Substance Addiction in Childhood and Adolescence. Deutsches Arzteblatt international, 118(1-2): 14-22. https://doi.org/10.3238/arztebl.m2021.0002

5. Masaeli N, Farhadi H. (2021) Prevalence of Internet-based addictive behaviours during COVID-19 pandemic: a systematic review. J Addict Dis.; 22:1-27.

6. Zuckerman A. (2020) Internet addiction statistics, 2020/2021 data, facts and predictions, Compare Camp.

7. Buneviciene I, Bunevicius A. (2021) Prevalence of internet addiction in healthcare professionals: Systematic review and meta-analysis. Int J Soc Psychiatry.;67(5):483-491.

8. Goldberg, Lewis R. (1992) The development of markers for the Big-Five factor structure. Psychological assessment 4.1: 26.

9. Tian Y, Zhao Y, Lv F, Qin N, Chen P. (2021) Associations Among the Big Five Personality Traits, Maladaptive Cognitions, and Internet Addiction Across Three Time Measurements in 3 Months During the COVID-19 Pandemic. Front Psychol.; 12:654825. Published 2021 May 20. doi:10.3389/fpsyg.2021.654825

10. Zhang, Y., Liu, Z., \& Zhao, Y. (2021). Impulsivity, Social Support and Depression Are Associated With Latent Profiles of Internet Addiction Among Male College Freshmen. Frontiers in psychiatry; 12, 642914. https://doi.org/10.3389/ fpsyt.2021.642914

11. Chwaszcz, J., Lelonek-Kuleta, B., Wiechetek, M., Niewiadomska, I., \& Palacz-Chrisidis, A. (2018). Personality Traits, Strategies for Coping with Stress and the Level of Internet Addiction-A Study of Polish Secondary-School Students. International journal of environmental research and public health; 15(5), 987. https:// doi.org/10.3390/ijerph15050987

12. Farahani, M., Alavi, S. S., Mirzamani Bafghi, M., Esmaili Alamuti, S., Taghavi, Z., \& Mohammadi, M. (2018). Psychological Factors Including Demographic Features, Mental Illnesses, and Personality Disorders as Predictors in Internet Addiction Disorder. Iranian journal of psychiatry; 13(2): 103-110.

13. Cerniglia, L., Cimino, S., Marzilli, E., Pascale, E., \& Tambelli, R. (2020). Associations Among 
Internet Addiction, Genetic Polymorphisms, Family Functioning, and Psychopathological Risk: Cross-Sectional Exploratory Study. JMIR mental health; 7(12), e17341. https://doi. org/10.2196/17341

14. Lo, B., Lai, R., Ng, T. K., \& Wang, H. (2020). Worry and Permissive Parenting in Association with the Development of Internet Addiction in Children. International journal of environmental research and public health; 17(21), 7722. https:// doi.org/10.3390/ijerph17217722

15. Yang, W., Morita, N., Zuo, Z., Kawaida, K., Ogai, Y., Saito, T., \& Hu, W. (2021). Maladaptive Perfectionism and Internet Addiction among Chinese College Students: A Moderated Mediation Model of Depression and Gender. International journal of environmental research and public health, 18(5), 2748. https://doi.org/10.3390/ ijerph18052748

16. Demkow-Jania, M., Kopera, M., Trucco, E. M., Kobyliński, P., Klimkiewicz, A., Abramowska, M., Mach, A., \& Jakubczyk, A. (2021). Substance Use Disorder Status Moderates the Association between Personality Traits and Problematic Mobile Phone/Internet Use. Journal of clinical medicine, 10(5), 919. https://doi.org/10.3390/ jem10050919

17. Sindermann, C., Sariyska, R., Lachmann, B., Brand, M., \& Montag, C. (2018). Associations between the dark triad of personality and unspecified/specific forms of Internet-use disorder. Journal of behavioral addictions; 7(4): 985992. https://doi.org/10.1556/2006.7.2018.114

18. Restrepo, A., Scheininger, T., Clucas, J., Alexander, L., Salum, G. A., Georgiades, K., Paksarian, D., Merikangas, K. R., \& Milham, M. P. (2020). Problematic internet use in children and adolescents: associations with psychiatric disorders and impairment. BMC psychiatry, 20(1), 252. https:// doi.org/10.1186/s12888-020-02640-x

19. Kim D., Lee J. (2021) Addictive Internet Gaming Usage among Korean Adolescents before and after the Outbreak of the COVID-19 Pandemic: A Comparison of the Latent Profiles in 2018 and 2020. Int J Environ Res Public Health.; 18(14): 7275.
20. Weinstein A. M. (2017). An Update Overview on Brain Imaging Studies of Internet Gaming Disorder. Frontiers in psychiatry, 8, 185. https://doi. org/10.3389/fpsyt.2017.00185

21. Brand M, Young K, Laier C. (2014) Prefrontal Control and Internet Addiction: A Theoretical Model and Review of Neuropsychological and Neuroimaging Findings. Front Hum Neurosci.; 8: 375 .

22. Wee CY, Zhao Z, Yap PT, Wu G, Shi F, Price T, Du Y, Xu J, Zhou Y, Shen D. (2014) Disrupted brain functional network in internet addiction disorder: a resting-state functional magnetic resonance imaging study. PLoS One. 2014 Sep 16;9(9):e107306. doi: 10.1371/journal.pone.0107306. PMID: 25226035; PMCID: PMC4165900.

23. Cheng H. (2020 Cheng, H., \& Liu, J. (2020). Alterations in Amygdala Connectivity in Internet Addiction Disorder. Scientific reports, 10(1), 2370. https://doi.org/10.1038/s41598-02059195-w

24. Baojuan Li, Razi A. Friston KJ. (2017) Editorial: Mapping Psychopathology with fMRI and Effective Connectivity Analysis. Front. Hum. Neurosci. 11, : 151. Published online $2021 \mathrm{Jul}$ 7. doi: $10.3390 /$ ijerph 18147275

25. Dresp-Langley B. Children's Health in the Digital Age. Int J Environ Res Public Health. 2020 May 6;17(9):3240. doi: 10.3390/ijerph17093240. PMID: 32384728; PMCID: PMC7246471.

26. Huang, Y., Xu, L., Kuang, L., Wang, W., Cao, J., \& Xiao, M. N. (2020). Abnormal brain activity in adolescents with Internet addiction who attempt suicide: an assessment using functional magnetic resonance imaging. Neural regeneration research, 15(8), 1554-1559. https://doi. org/10.4103/1673-5374.274346

27. Awan, H. A., Aamir, A., Diwan, M. N., Ullah, I., Pereira-Sanchez, V., Ramalho, R., Orsolini, L., de Filippis, R., Ojeahere, M. I., Ransing, R., Vadsaria, A. K., \& Virani, S. (2021). Internet and Pornography Use During the COVID-19 Pandemic: Presumed Impact and What Can Be Done. Frontiers in psychiatry, 12, 623508. https://doi.org/10.3389/fpsyt.2021.623508 


\title{
Резиме
}

\section{НЕВРОПСИХОЛОШКИ КОРЕЛАТИ НА ЗАВИСНОСТА ОД ИНТЕРНЕТ}

\author{
Нада Поп-Јорданова ${ }^{1}$ и Софија Лолеска ${ }^{2}$ \\ ${ }^{1}$ Македонска академија на науките и уметностите \\ 2 Докторанд на Медицинскиот факултет, Св. Кирил и Методиј, Скопје, Северна Македонија
}

Интернетот, мобилните телефони и другите слични алатки се неопходни за тековното функционирање, како во приватниот живот така и во бизнисот. Во овие две години од периодот на пандемија, користењето интернет, особено различните игри, како и мобилните телефони се без замена за глобалната популација.

Зависноста од интернет е дефинирана како психолошка, без оглед на видот на активност откако еднаш ќе се најавите. До денес студиите потврдија корелација на стресот, депресијата и вознемиреноста со зависноста од интернет. Докажано е и дека интернет-зависноста сама по себе го зголемува ризикот од депресија, вознемиреност и стрес. Покрај тоа, пандемијата на КОВИД 19 генерираше и промовираше социјална изолација и немање контрола на времето пред екранот, кои се главните причини за интернет-зависност.

Целта на овој напис е да даде краток преглед на истражувањата за зависноста од интернет, терминологијата и, особено, симптомите поврзани со работата на мозокот. Изворот на материјалот беа написите наведени во базата на податоци PubMed. Нашиот интерес беше особено ориентиран кон карактеристиките на личноста на корисниците и зависниците, како и наодите за невровизуализација кај погодените луѓе. Селектиравме најнови статии, објавени во периодот 2012-2021 година, кои се повеќе од 2000. Избраните добиени резултати ќе бидат презентирани и дискутирани.

Клучни зборови: зависност од интернет, психолошки фактори, невровизуализација 